\title{
MORPHOTECTONIC ANALYSIS OF THE NEOTECTONIC AND ACTIVE FAULTS OF BEOTIA (CENTRAL GREECE), USING G.I.S. TECHNIQUES
}

\author{
Sboras S. ${ }^{1}$, Ganas A. ${ }^{2}$, Pavlides S. ${ }^{1}$ \\ ${ }^{1}$ Aristotle University of Thessaloniki, Department of Geology, 54124 Thessaloniki, Greece, \\ pavlides@geo.auth.gr \\ ${ }^{2}$ Institute of Geodynamics, National Observatory of Athens, aganas@gein.noa.gr
}

\begin{abstract}
We study the neotectonic regime and evolution of the central-eastern part of the Asopos River basin (Beotia, Central Greece) which is an area undergoing crustal extension. The main tools that were used in this research were a) field mapping of neotectonic and active normal faults and b) morphotectonic analysis of 59 catchments, which was carried out by GIS techniques. Our results include a) series of maps displaying the spatial variation of morphotectonic indices (sinuosity, asymmetry factor, valley-floor-to-height-ratio etc) and b) map of neotectonic fault segments with associated faultslip data. The morphotectonic analysis indicates that if normal faults in this area are active, they are capable of generating earthquakes with $M>6.0$.
\end{abstract}

Key words: Morphotectonics, active faults, GIS, Asopos, Beotia, Greece.

\section{Geological setting}

The study area lies between the Gulfs of Corinth and Evia, two major rift structures oriented WNWESE and NW-SE, respectively. The land between the two gulfs is an area of low strain where river Asopos flows along a longitudinal basin (striking E-W; Asopos basin) controlled by active faults. The southern margin of the basin forms the northern side of the Parnitha and Kitheronas mountains. The pre-rift rocks of the region belong to the Sub-Pelagonian zone of the Hellenides, the western slope of the Cimmerian microcontinent (Smith et al., 1979; Robertson et al., 1991). Geodetic, geological and seismological data suggest that the present tectonic regime of Central Greece is extensional in a N-S to NE-SW direction as a complex result related both to back-arc extension behind the Hellenic subduction zone and the transtensional tectonic regime that originates from the dextral strike-slip motion of the North Anatolian Fault and its extension to the North Aegean Trough (McKenzie, 1972; 1978; Le Pichon and Angelier, 1979; Jackson and McKenzie, 1988; Hatzfeld, 1993; Papazachos and Kiratzi, 1996; Kahle et al., 1998; Clarke et al., 1998; El-Fiky, 2000; Doutsos and Kokkalas, 2001; Jolivet, 2001; Papazachos 2002; Armijo et al., 2003; Hubert-Ferrari et al., 2003; Kreemer and Chamot-Rooke, 2004; Kreemer et al. 2004; Ganas et al., 2005; Kokkalas et al., 2006; Hollenstein et al., 2008; Jolivet and Brun, 2008).

The two prominent basins of the study area are the Thiva and Asopos basins. The first is restrained and partially drained by Yliki and Paralimni Lakes (Papanikolaou et al., 1988) and was not considered suitable for morphotectonic analysis. The Asopos basin, took its name from the homonymous 
river, flows from the western part of Attiki Peninsula near Gulf of Corinth to the Gulf of Evia, running almost straight for a distance of about $50 \mathrm{~km}$ (Sboras et al., 2006). The basin started to form during Miocene according to Papanikolaou et al. (1988) and Mettos et al., (2000). Tectonic activity affects drainage patterns, causing several changes in the flow direction of Asopos River. According to a study of borehole data by Dounas et al. (1978), during Neogene times and near to the village Aghios Thomas the river was flowing 500-800 m southern from its present position. The evolution model of Asopos Basin, suggested by Papanikolaou et al. (1988), refers to a change in the tectonic regime during Quaternary causing uplift, erosion of the Miocene sediments and maintenance of terrestrial basin remnants. The topography of the northern side of Parnitha is characterized by high peaks with steep slopes, deep valleys and isolated highlands, while the low-lying sub-basin of Schimatari (mean elevation $100-200 \mathrm{~m}$ ) is the main receiver of the eroded material from the surrounding mountains.

Two major lithological units occur in the study area. The first is pre-rift rocks comprising Mesozoic alpine carbonates (limestones and dolomites), and the second consists of post-alpine sedimentary formations divided into two sub-units: the Neogene sediments, that comprise from bottom to top lacustrine-lagoon formations and terrestrial-fluvial formations, respectively, and the Quaternary sediments consisting of alluvial, debris and colluvium (Dounas et al. 1978).

The first attempt for morphotectonic investigation was made by Papanikolaou et al. (1988). They analyzed the drainage network and the slope morphology of Asopos Basin concluding that the area is under active tectonic control with rotating blocks. Mariolakos et al. (1997; 2001) studied the neotectonic structures of Avlonas region and the broader Western Parnitha, suggesting a complex tectonic setting with a diverging tilting from the western and eastern part of Koukistras Stream. An active fault investigation was conducted by Goldsworthy et al. (2002) further more to the north, towards Thiva Basin. These authors describe a fault system in the local area of Kallithea village consisting of south dipping normal faults that bound the southern sides of low, parallel, limestone ridges. Exposed fault surfaces strike between $\mathrm{N} 080^{\circ} \mathrm{E}$ and $\mathrm{N} 115^{\circ} \mathrm{E}$ with striations indicating slip vector azimuths between $180-200^{\circ}$. Tsodoulos et al. (2008) performed a morphotectonic analysis in the Erythres-Dafni Fault zone which consists of two left-stepping overlapped segments. They used many geomorphic parameters which all conclude in fault's high activity. The region to the west of the Asopos basin was mapped by Ganas et al. (2007), who also report evidence of active faulting.

The broader region has suffered from several catastrophic earthquakes many of which are known from historical references. According to the earthquake catalogue of Papazachos and Papazachou (1997), the vicinity of Thiva was struck four times since $14^{\text {th }}$ century: in $1321(\mathrm{M}=6.3)$, in 1853 (M = 6.8), in $1893(\mathrm{M}=6.2)$ and in $1914(\mathrm{M}=6.0)$. Ambraseys and Jackson (1990) also give information about the 1893 and 1914 events. For the latter they suggest an E-W striking fault located between Kallithea and Asopia villages. For the broader area of Beotia - Attica, the known earthquakes are in 1938, Oropos $(M=6.0)$, in 1981, Alkyonides $(M=6.7)$ and in 1999, Athens $(M=5.9)$ (Ambraseys and Jakson, 1990; Ganas et al., 2004; Jackson et al., 1982; Papazachos and Papazachou, 1997). The first two events occurred inside the highly active grabens of Evia and Corinth Gulfs respectively, while the last one was an "unexpected" event occurred near the city's limits.

\section{Methods}

\subsection{General}

The neotectonic field mapping in the Tanagra-Avlona-Asopos region (scale 1:50000) indicates the existence of nine (9) major WNW-trending normal faults (Tanagra, Asopia-Asopos, Megalos Schi- 


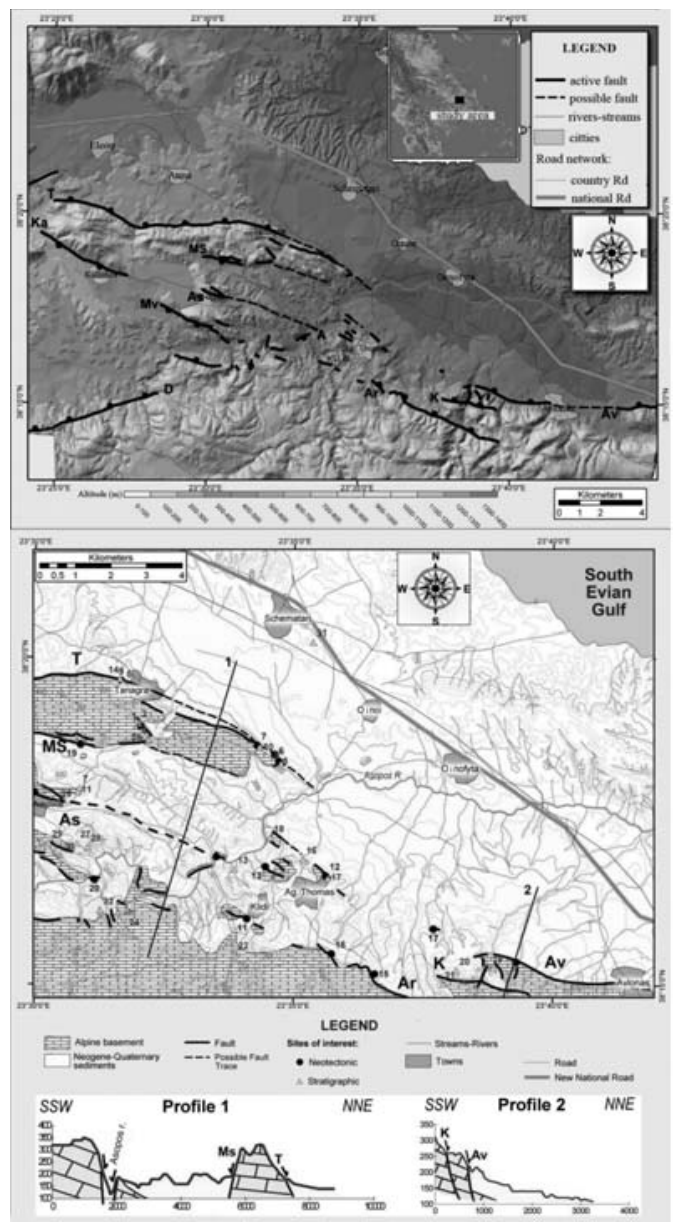

Fig. 1: Top: Neotectonic map of the study area, based on field mapping. T: Tanagra fault, Ka: Kallithea fault, Ar: Armakas fault, K: Koryfoula fault, Av: Avlonas fault, Mv: Mavrovouni fault, As and A: Asopia and Asopos fault, MS: Megalos Schinos fault and D: Dafne fault. Bottom: A more detailed geological map showing the investigated faults accompanied with two cross sections (numbered black lines). Lithological formations are simplified.

nos, Armakas, Koryfoula, Dafne, Avlona, Kallithea and Mavrovouni) with lengths more than $3 \mathrm{~km}$. Many smaller fault segments are also present mainly striking WNW-ESE to NW-SE. The dominant dip direction is toward NNE. However, there are many antithetic faults that can also be observed, occupying the foothills of elongated limestone ridges. This pattern results in the formation of small parallel grabens and horsts. There are also a few conjugate normal faults striking (ENE-WSW) SWNE, the largest of which is the Dafne fault (Figure 1).

Morphotectonic analysis is a powerful tool to help us detect and understand the processes that occur on the earth's surface. Tectonic movements and erosion leave their marks each in a different way and quantification of the morphological features is the key to associate the landscape with the neotectonic evolution of the region. Since morphotectonic analysis is a good indicator but not a stand-alone proof, it was performed after a morphotectonic-geological mapping. In order to achieve the most accurate results and their most distinctive presentation on different thematic maps, we used ArcGIS 8.1 software. The analysis was undertaken on a mosaic of four topographic maps in 1:50000 scale (HMGS). The maps were digitized, projected to the Greek National projection system (EGSA87) and a three-dimensional terrain model (DEM) was produced with a resolution of less than $20 \mathrm{~m}$. We also used a SPOT 1 satellite image with 10-m resolution (Figure 3a) and 1:15000 scale aerial photo- 
Table 1. Mathematical relationships for the morphotectonic indices that was applied in this paper (Keller and Pinter, 2002).

\begin{tabular}{|c|c|}
\hline Index & Relationship \\
\hline $\mathrm{AF}$ & $\mathrm{AF}=(\mathrm{Ar} / \mathrm{At}) 100$ \\
\hline TTSF & $\mathrm{TTSF}=\mathrm{Da} / \mathrm{Dd}$ \\
\hline Hypsometric Integral $(\mathrm{HI})$ & $\mathrm{HI}=\left(\mathrm{H}-\mathrm{H}_{\min }\right) /\left(\mathrm{H}_{\max }-\mathrm{H}_{\text {min }}\right)$ \\
\hline $\mathrm{V}_{\mathrm{f}}$ & $\mathrm{V}_{\mathrm{f}}=2 \mathrm{~V}_{\mathrm{fw}} /\left(\mathrm{h}_{1}-\mathrm{h}_{3}\right)+\left(\mathrm{h}_{2}-\mathrm{h}_{3}\right)$ \\
\hline $\mathrm{S}_{\mathrm{mf}}$ & $\mathrm{S}_{\mathrm{mf}}=\mathrm{L}_{\mathrm{mf}} / \mathrm{L}_{\mathrm{s}}$ \\
\hline
\end{tabular}

Ar: area of the basin to the right of the trunk stream, At: total area of the drainage basin, Da: distance from midline of the drainage basin to the midline of the river, $\mathrm{Dd}$ : distance from the basin midline to the basin di-vide, $\mathrm{H}$ : mean elevation, $\mathrm{H}_{\text {min: }}$ : minimum elevation, $\mathrm{H}_{\text {max }}$ : maximum elevation, $\mathrm{V}_{\mathrm{fw}}$ : valley floor width, $\mathrm{h}_{1}, \mathrm{~h}_{2}$ : elevations of left and right valley divides, $\mathrm{h}_{3}$ : elevation of the valley floor, $\mathrm{L}_{\mathrm{mf}}$ : length of the mountain front along the foot of the mountain, $\mathrm{L}_{\mathrm{s}}$ : straight-line length of the mountain front.

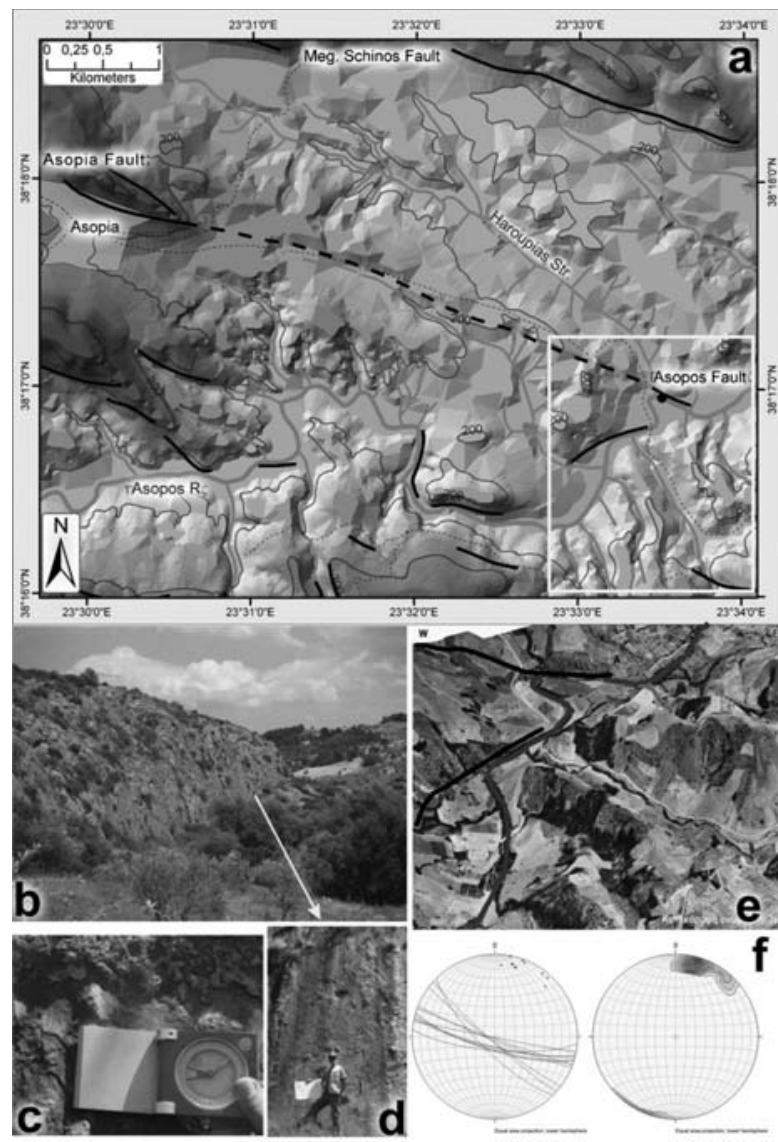

Fig. 2: a) DEM detail in the area of Asopia where the Asopia-Asopos Fault dominates. Contour lines every $100 \mathrm{~m}$. Thin lines are the drainage and the thick line is Asopos River. Black lines are faults. The white outlined box refers to following images (b)-(f). b) The scarp of Asopos Fault lying on Mesozoic limestones. c) Evidences of slickensides indicating the normal character of the fault. d) Corrugations on the fault's free face. e) Detail of how Asopos Fault (A) affects the homonymous river with the use of DEM and aerial photograph ( $3 \mathrm{x}$ vertical exaggeration). The river, flowing northwards, is initially affected by a minor fault and then curves into an $\mathrm{S}$ shape in order to flow parallel to the scarp. At the end of the scarp, the river changes again its flow to its initial direction.f) Mesostructural analysis of the Asopos Fault portrayed on lower hemisphere equal-area projections. Left diagram shows plot of fault planes, right diagram shows contours of poles to fault planes. Data indicate a dominant SSW dip direction. 


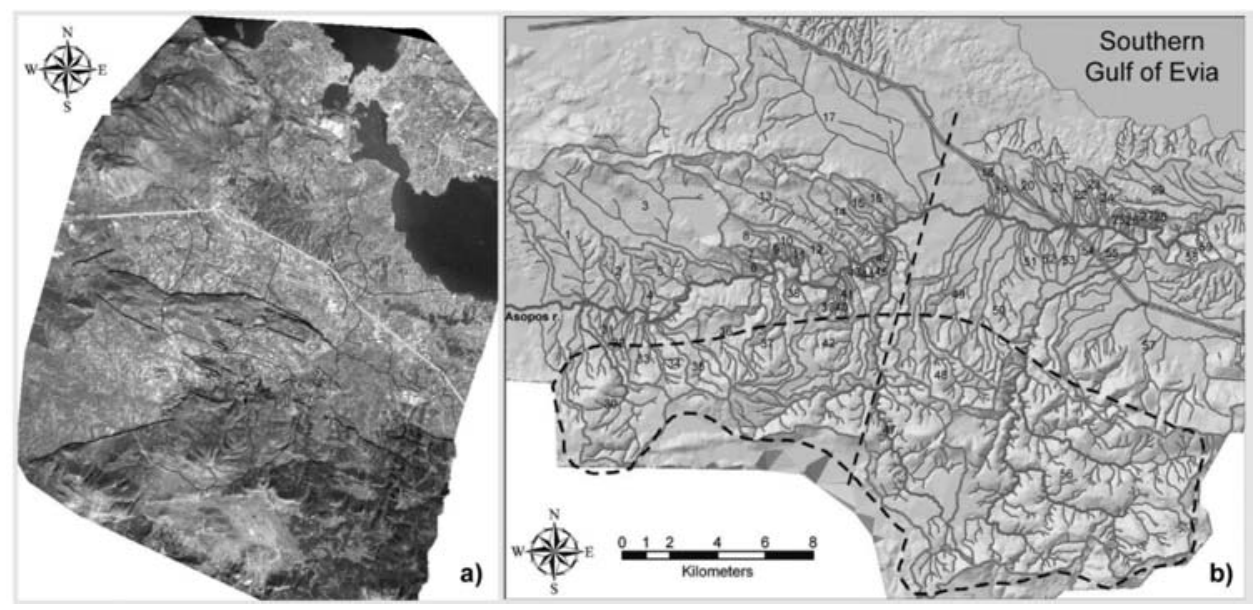

Fig. 3: a) DEM combined with a 10 m-resolution satellite image (SPOT 1). The major active tectonic structures are shown in black lines while the whitish line represents the National Road.b) DEM of the study area showing the drainage and the catchment deviation numbered. The National Road is also shown (thick grey line). The dashed outlined area and the dashed line are explained in the text.

graphs (HMGS) to locate precisely the fault segment boundaries (Figure 2e). The analysis comprised the calculation of morphotectonic indicators (asymmetry factor, transverse topographic symmetry, hypsometric curve, hypsometric integral, ratio of valley - floor width to valley height, mountain-front sinuosity - Table 1 shows the mathematical relationships) for 59 sub-basins in the central-eastern part of the Asopos basin, including also the cumulative one.

Some qualitative observations indicate a differentiation on the drainage network pattern and the shape and size of the catchments. The catchments south of Asopos River contain a denser, well-developed dendritic drainage network in contrast with the northern ones (curved dashed outlined area in Figure 3b) while their shape is larger and more complicated especially in the south-eastern part of the study area. In more detail, the main river seems to flow in the middle of the basin at the western part of the study area while it suddenly seems to flow nearer to the northern margin at the eastern part (left and right from the straight dashed line in Figure 3b, respectively). Some other local anomalies can be observed in the development pattern of some sub-basins, especially in the southern part of Asopos River. However, a more quantitative approach derives by calculating the following morphotectonic parameters.

\subsection{Data analysis}

The description of the analysed morphotectonic parameters and accompanied with short conclusions, follow below.

\subsubsection{Slope and Mean Slope}

An actual slope dipping distribution and a mean slope map of the sub-basins were produced in order to monitor abrupt morphological changes and to relatively compare each sub-basin. Results show that the catchments belonging to the southern part of Asopos Basin show greater values thus having a steeper relief. Here it should be noticed that high values in the actual or mean slope map are not seen 
only in the areas where the erosion-resistant Mesozoic limestones appear (mostly in the southern part of the study area). Concerning the actual slope map, values higher than $9^{\circ}$ and up to $15^{\circ}$ can be observed in a large part of the region where mostly post-alpine sediments occur. As we move upwards the northern side of Parnitha Mountain a range between $15^{\circ}$ to $30^{\circ}$ is observed. Values higher than $30^{\circ}$ appear only inside the narrow valleys and streams that lead to Asopos River, as well as in a part of the latter where Mavrovouni and Asopia-Asopos Faults control the local relief. The linear distribution of high values where active faults have been recognized and mapped can be also observed. The mean slope map shows that basins in the southern part of Asopos Basin have higher values suggesting a steeper morphology. Although high actual slope angles can be seen near mountains like Tefmissos and Kirykion, the surrounding basins 3 and 13 show low mean slope angles. That can be interpreted as a subdued relief but with prominent scarps which in this case are the Kallithea and Megalos Schinos Faults.

\subsubsection{Asymmetry Factor (AF)}

This morphotectonic indicator, described by Keller and Pinter (2002), is helpful to understand if and how drainage has been developed under tectonic control in a quantitative manner. It is essential to insure that lithology (like dipping sedimentary formations) is taken out of the calculations in order to isolate only the tectonic effects. Since the study area is not very large, we consider a uniform microclimate. The value range corresponds from 0 to $100 \%$. If the basin is not tilted then the $\mathrm{AF}$ is $50 \%$. Values under and over 50\% represent rightward and leftward tilting (according to the main river's flow), respectively. Sub-basin 3 shows high values of rightward tilting due to the existence of the NNE dipping Tanagra Fault north of the basin. The basin is situated on the footwall of the fault which causes a southern block rotation along a WNW-ESE trending axis. Sub-basin 14 shows an opposite rotation produced by the antithetic fault of the Tanagra Fault located at the southern foothills of Kirykio Mt. Sub-basin 48 has a low AF (29.71\%) due to the existence of Armakas Fault. The total basin of the study area has an $\mathrm{AF}$ of $65.1 \%$ which represents a northward rotation along an EW trending axis, parallel to the Asopos River (Fig. 4). This means that the whole area is affected by the WNW-ESE striking faults.

\subsubsection{Transverse Topographic Symmetry Factor (TTSF)}

This is another quantitative index to evaluate basin asymmetry (Keller and Pinter, 2002; Figure 4). Absence of tectonics would cause the main river to flow evenly from both sides forming a perfectly symmetric basin with a TTSF value of 0 . The TTSF value can be more than 0.0 and up to 1.0 , depending on tectonic intensity, since lithological reasons are isolated. Values near to 1.0 indicate that the river flows closely to the margins of the basin, a result probably produced by intensive and recent tectonic activity. For the same reasons like in the Asymmetry Factor, sub-basin 3 has a high value of TTSF. High values in some of the basins from the southern side of Asopos River cannot be explained tectonically since the orientation of the local faults (Armakas, Koryfoula and Avlonas) is transverse to the longest axis of the sub-basins. On the other hand there is a lithological alteration in this area, having the water-resistant limestones in contrast with the post-alpine sediments probably affecting the drainage network. Concerning the broader Asopos basin, the TTSF could not be applied once since Asopos River flows in the middle of the basin during the first half distance of its flow, and near the northern margin during the second one. According to the division in the map of Figure 3 (dashed line), in the western part of the basin TTSF is approximately 0.1 , while in the eastern part the value goes up to ca. 0.7. The distance between the two measurements are almost $10 \mathrm{~km}$. This abrupt change can only be explained by tectonic activity. 


\subsubsection{Hypsometric Curve-Hypsometric Integral (HI)}

Hypsometric Curve describes the distribution of elevations across an area of land and its Hypsometric Integral, which is defined as the area under the hypsometric curve, is the quantification of the curve's shape (Strahler, 1952; Pike and Wilson, 1971; Keller and Pinter, 2002). High values indicate a high topography relative to the mean, such as smooth upland surface cut by deeply incised streams, while low and intermediate values are associated with more evenly dissected drainage basins (Strahler, 1952; Keller and Pinter, 2002). A useful attribute of the latter is that it is independent of the basin size and relief. Sub-basins 1, 3, 17, 49, 50, 56 and 57 show low values of Hypsometric Integral indicating that these basins are in young stage (Figure 4). All these sub-basins are affected by many faults suggesting a possible uplift. The same happens to the Hypsometric Integral value of the broader basin $(\mathrm{H}=0.234)$ suggesting a tectonic uplift of the whole study area.

\subsubsection{Ratio of Valley - Floor Width to Valley Height $\left(V_{f}\right)$}

This morphological indicator is useful to quantitatively differentiate the shape along a transverse section of a valley. High values of $\mathrm{V}_{\mathrm{f}}$ indicate broad-floored $\mathrm{U}$-shaped canyons, while low values indicate deep V-shaped valleys with streams that are actively incising (Keller and Pinter, 2002). The latter case can be related with uplifting. This parameter could not be applied in many sub-basins because the size was too small for the DEM's resolution. However, it is significant that almost all subbasins located to the southern side of Asopos River have low ratio values (Figure 4). This can be interpreted as a tectonic uplift since these basins are situated on the footwall of the faults.

\subsubsection{Mountain-front Sinuosity $\left(S_{m f}\right)$}

The Mountain-front Sinuosity index is a useful morphotectonic tool especially in our study area where mountains and hills mainly consist of limestones. It reflects the balance between erosional and tectonic forces (Keller and Pinter, 2002). According to Pavlides (2003), a range between 1.0 and 1.6 is considered to be a tectonically highly active mountain front, 1.6 up to 3.0 less active and 3.0 and above inactive. It is important to notice that the value is affected by the map scale. In the case of our mapped faults (Fig. 5), wherever it was possible for the method to be applied, the calculated values are less than 1.6. The lowest values in ascending order belong to Asopia, Mavrovouni, Megalos Schinos and Kallithea Faults, while the highest values belong to Tanagra and Avlonas Faults.

\subsection{Evaluation of seismic potential}

According to the length of the mapped faults, we used the empirical relationships of Wells and Coppersmith (1994), Ambraseys and Jackson (1998) and Pavlides and Caputo (2004) in order to estimate the seismic potential magnitude for each fault. At this stage we do not differentiate among the faults, i.e. active vs. inactive. It is clear that the Asopos Fault is active (Figure 2) because it controls drainage and shows linear, relatively unerroded scarps along its strike. However, other faults like the Tanagra fault seem less likely to be active because no such scarps were found during field work. No good quality seismological data (from local networks) exist, in order to show microseismic activity in south Beotia. Therefore, the estimates shown in Table 2 should be used with caution and with considerable uncertainty as more field work is necessary. In Table 2, the seismic potential magnitude is shown, according to the above mentioned empirical relationships ( $\mathrm{W} \& \mathrm{C}, \mathrm{A} \& \mathrm{~J}, \mathrm{P} \& \mathrm{C}$ respectively). Abbreviation of fault names like in Figure 1. 
Table 2.

\begin{tabular}{|c|c|c|c|c|}
\hline Fault & Length $(\mathbf{k m})$ & $\boldsymbol{W} \& \boldsymbol{C}$ & $\boldsymbol{A} \& \boldsymbol{J}$ & $\boldsymbol{P} \& \boldsymbol{C}$ \\
\hline T & 16.5 & $6.5( \pm 0.6)$ & 6.5 & $6.6( \pm 0.5)$ \\
\hline MS & 6.5 & $5.9( \pm 0.5)$ & 6.1 & $6.2( \pm 0.7)$ \\
\hline As \& A & 5.0 & $5.8( \pm 0.5)$ & 5.9 & $6.1( \pm 0.3)$ \\
\hline Ar & 7.0 & $6.0( \pm 0.6)$ & 6.1 & $6.2( \pm 0.3)$ \\
\hline Ka \& Mv & 10.8 & $6.2( \pm 0.6)$ & 6.3 & $6.4( \pm 0.4)$ \\
\hline
\end{tabular}

The Asopia-Asopos Faults were considered segments of the same fault zone, thus we estimated the worst scenario for total activation. The same was considered for Kallithea-Mavrovouni Faults. Taking into account the results from Pavlides and Caputo (2004) relationship, each of the faults of table 2 is capable of earthquake magnitude > 6.0. The Avlon fault (further East; Ganas et al., 2004) is not calculated since it was not studied in all of its length

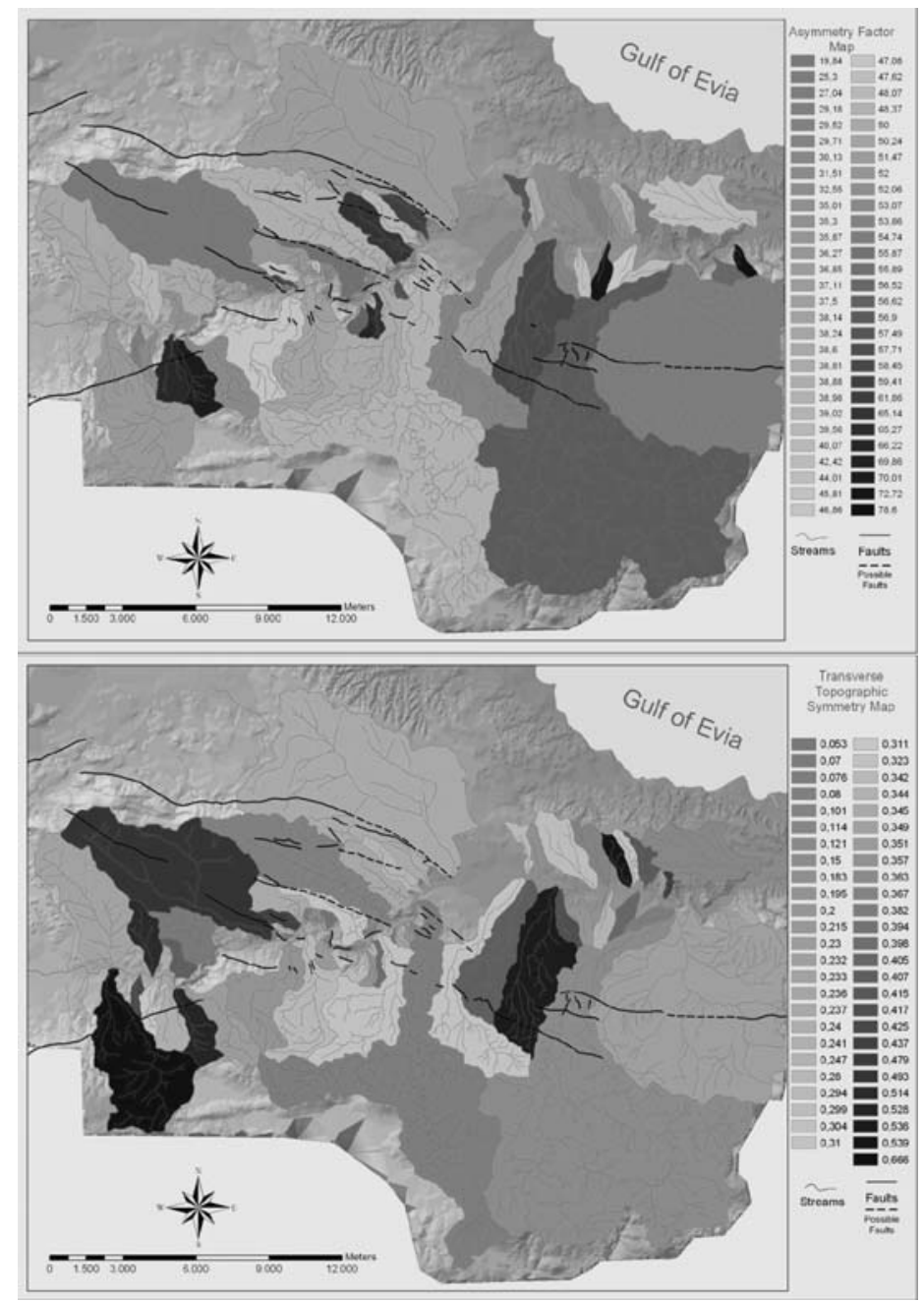



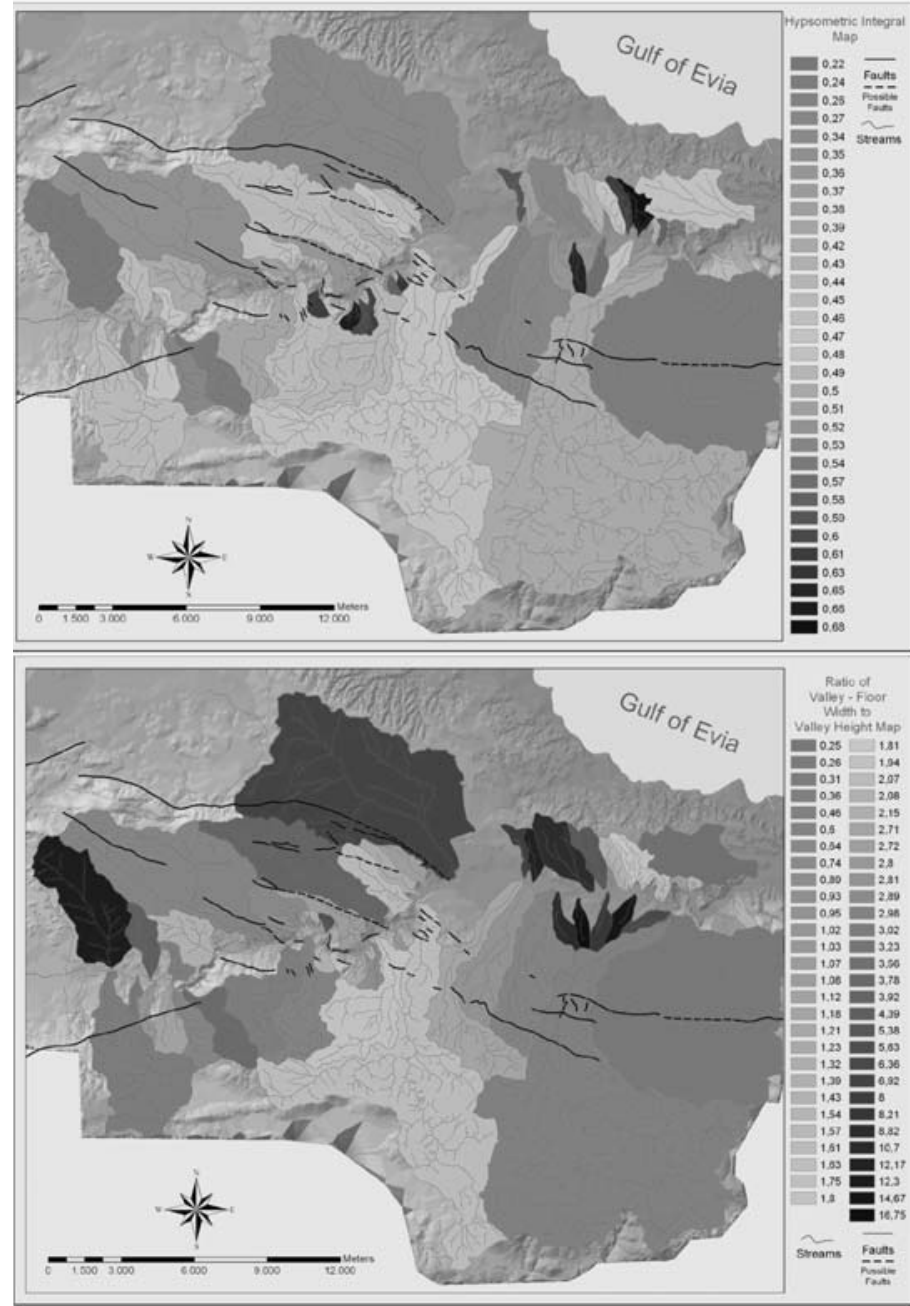

Fig. 4: Thematic maps produced after morphotectonic analyses in ARC GIS. The results of Asymmetry Factor, Transverse Topographic Symmetry Factor, Hypsometric Integral and Ratio of Valley-Floor Width to Valley Height are shown in order of appearance. Further explanation is found in the text.

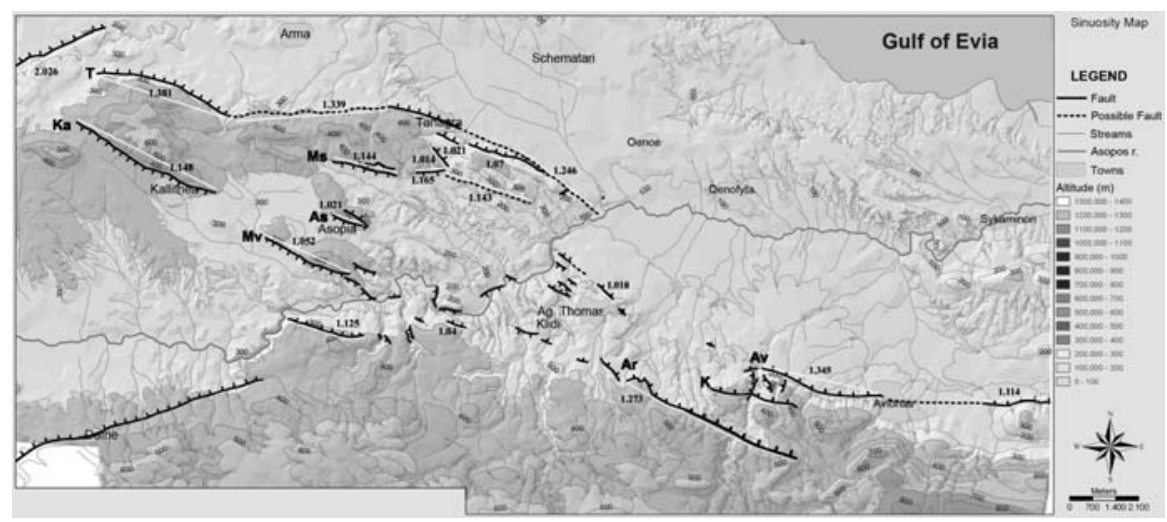

Fig. 5: Mountain Front Sinuosity map of the investigated area. 


\section{Conclusions}

We applied detailed morphotectonic analysis in the region of the Asopos rift in central - south Beotia region, central Greece (Figures 3,4 and 5). According to morphotectonic criteria, most mapped faults in the study area are considered as highly active, with the exception of Tanagra and Megalos Schinos faults (Figure 1), which display no clear geological and less geomorphological evidences of recent activity. Thus we characterized them as possible active in the sense that they can be triggered/activated as secondary structures. For the rest of the faults, on one hand our morphotectonic analysis and geological data suggest that they show evidence of recent and highly active tectonic movements, but on the other hand they have sparse seismic activity with long periods of quiescence as it derives from both historic and instrumental data. Evidence of high fault activity show the Avlona-Koryfoula-Armakas, Kallithea-Mavrovouni and Asopia-Asopos fault segments. Concerning the latter ones, Asopia fault segment although it seems morphologically less expressed than the Asopos Fault segment (southeastern extension; Figure 2) we suggest that they comprise two branches of the same fault.

\section{References}

Ambraseys, N.N. and Jackson, J.A., 1990. Seismicity and associated strain of central Greece between 1890 and 1988. Geoph. J. Int., 101, 663-708.

Ambraseys, N. and Jackson, J., 1998. Faulting associated with historical and recent earthquakes in the Eastern Mediterranean region. Geophys. J. Int., 133, 390-406

Armijo, R., Flerit, F., King, G., and Meyer, B., 2003. Linear elastic fracture mechanics explains the past and present evolution of the Aegean. Earth Plan. Sci. Lett., 217, 85-95

Clarke, P.J., Davies, R.R., England, D.C., Parsons, B., Billiris, H., Paradissis, D., Veis, G., Cross, P.A., Denys, P.H., Ashkenazi, V., Bingley, R., Kahle, H.-G., Muller, M.V. and Briole, P., 1998. Crustal strain in central Greece from repeated G.P.S., measurements in the interval 1988-1997. Geoph. J. Int., 135, 195-214

Dounas, A., Kallergis, G., Morfis, A. and Pagounis, M., 1978. Hydrogeological investigation on the Asopos river valley. IGME Publications, 21, Athens

Doutsos, T. and Kokkalas, S., 2001. Stress and deformation patterns in the Aegean region. Journal of Structural Geology, 23, 455-472

El-Fiky, G.S., 2000. Crustal Strains in the Eastern Mediterranean and Middle East as Derived from GPS Observations. Bull. Earthq. Res. Inst. Univ. Tokyo, 75, 105-125

Ganas, A., Pavlides, S.B., Sboras, S., Valkaniotis, S., Papaioannou, S., Alexandris, G.A., Plessa, A., and Papadopoulos, G. A., 2004. Active Fault Geometry and Kinematics in Parnitha Mountain, Attica, Greece. J. Struct. Geol., 26, 2103-2118.

Ganas, A., Drakatos, G., Pavlides, S.B, Stavrakakis, G.N, Ziazia, M., Sokos, E., and Karastathis, V.K., 2005: The $2001 \mathrm{Mw}=6.4$ Skyros earthquake, conjugate strike-slip faulting and spatial variation in stress within the central Aegean Sea. Journal of Geodynamics, 39, 61-77.

Ganas, A., Spina, V., Alexandropoulou, N., Oikonomou, A., and Drakatos, G., 2007. The Corini active fault in south-western Beotia region, central Greece: segmentation, stress analysis and extensional strain patterns. Bull. Geol. Soc. Greece, 40, 297-308.

Goldsworthy, M., Jackson, J. and Haines J., 2002. The continuity of active fault systems in Greece. Geophys. J.Int., 148, 596-618

Hatzfeld, D., 1993. Geodynamics of the Aegean: A microseismotectonic approach. Ann. Geofis., 36 (2), 215-228 
Hollenstein, C., Müller, M. D., Geiger, A. and Kahle H.-G., 2008: Crustal motion and deformation in Greece from a decade of GPS measurements, 1993-2003. Tectonophysics, 449, 17-40

Hubert-Ferrari, A., King, G., Manighetti, I., Armijo, R., Meyer, B. and Tapponnier, P., 2003. Long-term elasticity in the continental lithosphere; modelling the Aden Ridge propagation and the Anatolian extrusion process. Geophys. J.Int., 153, 111-132

Jackson, J.A., Gagnepain, J., Houseman, G., King, G.C.P., Papadimitriou, P., Soufleris, C., Virieux, J., 1982. Seismicity, normal faulting, and the geomorphological development of the Gulf of Corinth (Greece): the Corinth earthquakes of February and March 1981. Earth Plan. Sci. Lett., 57, 377-397

Jackson, J. and McKenzie, D., 1988. Rates of active deformation in the Aegean Sea and surrounding regions. Basin Research, 1, 127-128

Jolivet, L., 2001. A comparison of geodetic and finite strain pattern in the Aegean, geodynamic implications. Earth Plan. Sci. Lett., 187, 95-104

Jolivet, L. and Brun, J.-P., 2008. Cenozoic geodynamic evolution of the Aegean. Int. J. Earth Sci., (Published online), doi: 10.1007/s00531-008-0366-4

Kahle, H., Straub, C., Reilinger, R., McClusky, S., King, R., Hurst, K., Veis, G., Kastens, K. and Cross, P., 1998. The strain rate field in the eastern Mediterranean region, estimated by repeated GPS measurements. Tectonophysics, 294, 237-252

Keller, A. and Pinter, N., 2002: Active Tectonics: Earthquakes, Uplift and Landscape. Prentice Hall, N. Jersey, Second Edition, pp 377

Kokkalas, S., Xypolias, P., Koukouvelas, I., and Doutsos, T., 2006, Postcollisional contractional and extensional deformation in the Aegean region. In Dilek, Y., and Pavlides, S. (eds), Postcollisional tectonics and magmatism in the Mediterranean region and Asia: Geol. Soc. Am. Special Paper, 409, 97-123

Kreemer, C. and Chamot-Rooke, N., 2004. Contemporary kinematics of the southern Aegean and the Mediterranean Ridge. Geophys. J. Int., 157, 1377-1392

Kreemer, C., Chamot-Rooke, N. and Le Pichon, X., 2004. Constraints on the evolution and vertical coherency of deformation in the Northern Aegean from a comparison of geodetic, geologic and seismologic data. Earth Plan. Sci. Lett., 225, 329-346

Le Pichon, X., and Angelier, J., 1979. The Hellenic Arc and trench system: a key to the neotectonic evolution of the Eastern Mediterranean area. Tectonophysics, 60, 1-42.

McKenzie, D.P., 1972. Active tectonics of the Mediterranean region. Geoph. J. R. Astr. Soc., 30, 2, 109185

McKenzie, D.P., 1978. Active tectonics of the Alpine-Himalayan belt: the Aegean Sea and surrounding regions. Geoph. J. R. Astr. Soc., 55, 217-254.

Mariolakos, I., Fountoulis, I. and Logos, E., 1997: The crucial role of the neotectonic deformation at the landfill site selection. The case study of Avlona (Attiki, Greece). Proc. Int. I.A.E.G., 2, Balkema, Rotterdam, 2007-2010

Mariolakos, I., Fountoulis, I., Sideris, C. and Hatoupis, T., 2001. The morphotectonic structure of Parnis Mt. (Attica, Greece). BuII. Geol. Soc. Greece, 34, 1, 183-190

Mettos, A., Ioakim, C. and Rondoyanni, T., 2000: Palaeoclimatic and palaeogeographic evolution of Attica-Beotia (Central Greece). Geol. Soc. Greece, Special Publications, 9, 187-196.

Papanikolaou, D.J., Mariolakos, I.D., Lekkas E.L. and Lozios, S.G., 1988. Morphotectonic observations on the Asopos Basin and the Coastal zone of Oropos. Contribution to the Neotektonics of Northern Attica. Bull. Geol. Soc. Greece, 20, 1, 251-267

Papazachos, C.B., 2002. The active crustal deformation field of the Aegean area inferred from seismic- 
ity and GPS data. WEGENER 2002, Eleventh general Assembly of the Wegener Project, Athens, Greece, 12-14 June 2002

Papazachos, C.B. and Kiratzi, A.A., 1996. A detailed study of the active crustal deformation in the Aegean and surrounding area. Tectonophysics, 253, 129-153

Papazachos, B. and Papazachou, C., 1997. The Earthquakes of Greece. Thessaloniki, editions Ziti, 304

Pavlides, S., 2003. The Geology of Earthquakes (in Greek). Thessaloniki, University Studio Press, 378

Pavlides, S and Caputo, R., 2004. Magnitude versus faults' surface parameters: quantitative relationships from the Aegean Region. Tectonophysics, 380, 159-188

Pike, R.J. and Wilson, S.E., 1971. Elevation-relief ratio, hypsometric integral and geomorphic area-altitude analysis. Bull. Geol.Soc. Am., 82, 1079-1083

Robertson, A.H.F., Clift, P.D., Degnan, P., Jones, G., 1991. Palaeogeographic and palaeotectonic evolution of the Eastern Mediterranean Neotethys. Palaeogeography, Palaeoclimatology, Palaeoecology, 87, 289-344

Sboras, S., Ganas, A., Pavlides, S., 2006. Tectonic Geomorphology and active tectonics of the Asopos Rift valley, central Greece. 11th International Symposium on Natural and Human Induced Hazards \& 2nd Workshop on Earthquake Prediction Abstract Volume, June 22-25, 2006, Patras, Greece, page 95.

Smith, A.G., Woodcock, N.H., and Naylor, M.A., 1979. The structural evolution of a Mesozoic continental margin, Othris Mountain, Greece. Jour. Geol. Soc. London, 136, 589-603.

Strahler, A.N., 1952: Hypsometric (area-altitude) analysis of erosional topography. Bull. Geol. Soc. Am., $63,1117-1142$

Tsodoulos, I.M., Koukouvelas, I.K. and Pavlides, S., 2008. Tectonic geomorphology of the easternmost extension of the Gulf of Corinth (Beotia, Central Greece). Tectonophysics, 453, 211-232

Wells, D.L. and Coppersmith, J.K., 1994. New empirical relationships among magnitude, rupture length, rupture width, rupture area, and surface displacement. Bull. Seismol. Soc. Am., 84, 974-1002 